\title{
Assessment of Welfare Shocks and Food Insecurity in Ephraim Mogale and Greater Tubatse Municipality Of Sekhukhune Districts, Limpopo Province, South Africa
}

\author{
Peter Temitope Agboola ${ }^{1}$, Abayomi Samuel Oyekale ${ }^{2}$,Oduniyi Oluwaseun \\ Samuel $^{3}$ \\ (Agricultural Economics) Department of Agriculture and Animal Health University of South Africa, Florida \\ Campus, Roodepoort. South Africa \\ (Agricultural Economics) Department of Agriculture and Animal Health University of North West. South Africa
}

\begin{abstract}
This study has assessed the welfare shocks and household food Insecurity in Ephraim Mogale and Greater Tubatse municipality of Sekhukhune district, Limpopo Province in South Africa. The study identified shocks affecting livelihood at household level and also determined the food insecurity status of households. Structured questionnaire was administered for data collection. Two hundred households were involved in the study with 100 households selected from each municipality. All response from the questionnaires was tabulated and processed with the use of statistical package for social sciences (SPSS) programme. Three analytical tools were used to achieve the objectives of the study such as, Descriptive statistics, Household Food insecurity Assessment Scale (HFIAS) and linear regression model. Majority of households experience different form of shocks in their households. Increase in food prices, high level of livestock disease, drought, death of a household member and chronic illness such as Diabetes, HIV/AIDS and Tuberculosis are the most important shocks experienced. Approximately $22.2 \%$ of households were characterized as being food secure, $32.2 \%$ as mildly food insecure, $34.2 \%$ as moderately food insecure while $11.4 \%$ are severely food insecure. The main determinants of food security from the sample survey were Education, Unskilled wage labour, Grants, pension and disability funds whereby high-level of livestock diseases, illness or accidental loss, death of an household member tends to expose households to higher risk of food insecurity. Policy recommendations are made on promoting education, industrialization, employment opportunities in the rural areas.
\end{abstract}

Keywords: Household Food insecurity, welfare shocks, linear regression, Sekhukhune, Limpopo Province.

\section{Introduction}

Food insecurity at households is still a major challenge. The level of food insecurity is on the increase in many South African households (Altman et al., 2009). Estimates of the number of South Africans who are food insecure range from 50\% (National Department of Agriculture, 2002) to 52\% (Labadarios et al., 2009), and up to $80 \%$ (Jacobs, 2009). The variations in the above national-level estimates could be ascribed to the different measures used to determine food insecurity line (e.g., under-nutrition versus under-nourishment) and the type of survey data upon which each study was based. These estimates, despite the differences, highlight the severity of food insecurity at households' level in South Africa.

According to The Centre for Poverty, Employment and Growth (CPEG), food security in households is the focal area of concentration of the CPEG, and is a crucial component of their poverty and unemployment reduction efforts. This Centre discovered that food insecurity has been a major problem facing South African households with incessant poverty and unemployment being the major causes (HSRC 2007). These circumstances were caused due to the increase rate of shocks affecting households in the country. These conditions have exposed many South African households to different levels of shocks and stressors, including droughts, HIV/AIDS, poor education, increase in food prices, and climate change.

The increasing levels of these shocks have become a major concern in the country. According to a national report released in 2014 that concurred with World Hunger Day, South Africa is the second largest economy in Africa, but only $46 \%$ of South Africans are food secure, and $26 \%$ of the country's population experience chronic starvations (Shisana et al., 2014). Frequent occurrence of drought and floods are found to be common in the country. This has led to several disasters in terms of economic loss due to poor farming output. Agri SA (2015) discovered that inadequate amount of rainfall have negatively affects maize farmers in Free State. This situation has made farmers to be in need of huge financial support in order to recover from this problem due to the magnitude of the drought.

The highest number of individuals living with HIV/AIDS in the world is in South Africa (IFAD, 2007 [Online]). The total number of 5.2 million people are estimated to be HIV positive, representing an HIVcommonness rate of $10.6 \%$ among the total estimated population. (Haldenwang, 2009: 2). This disease has been 
a challenge to the whole world and South Africa faces this today. Approximately 3.2 million individuals worldwide were living with HIV/AIDS in 2007 (UNAIDS, WHO, 2007), and lots of lives have been lost due to this disease. This epidemic is affecting many households in the country, thereby exposing them to adverse economic conditions.

\section{Objectives of the study}

The main objective of the study is to analyze the effect of welfare shocks and food insecurity in Ephraim Mogale and Greater Tubatse Municipalities in Sekhukhune District of Limpopo Province.

The specific objectives are:

I. To identify shocks affecting livelihood at household level

II. To determine the food insecure status of households

III. Identify the impact of shocks along with other factors on food insecurity

IV. To make policy recommendations based on the four major findings from the study.

\section{Research questions}

The study aimed at answering the following research questions.

I. What are the shocks affecting livelihood at household level in Sekhukhune district and how it can be eradicated?

II. What is the recent state of food security at household level in Sekhukhune District?

III. What are the determinants of food security at household level in Sekhukhune?

IV. At what effect does shocks influence food security at household level in Sekhukhune district?

\section{Materials And Method}

The survey was conducted in Sekhukhune district of Limpopo province. The district is situated in the south-eastern part of Limpopo province. Two local municipalities were chosen out of five municipalities in the district. This is because the two municipalities are the most populated local municipalities in the district. Sekhukhune district is one of the five districts in Limpopo province. The Greater Sekhukhune District municipality was established in December 2000. This district consist of five local municipalities namely, Fetakgomo, Makhuduthamaga, Elias Motsoaledi, Ephraim Mogale and Greater Tubatse local municipalities (Stats SA, 2011). The vast majority of the district is mostly rural, with approximately $94.7 \%$ of the population living in the rural areas and 5.3\% living in the urban areas.

Greater Tubatse local municipality was incorporated in the year 2000, after the local government elections. This area came out as a result of the municipal segregation process. The area is made up of 29 wards and 166 villages with its main office in Burgersfort. Each ward is represented by a councillor which is managed by a local municipality. Their focal commercial economic sectors are mining, agriculture, civil services and retail services.

Ephraim Mogale local municipality was incorporated in the year 2000. The municipality was integrated into Limpopo province after the municipal election in the year 2006. The municipality came out as a result of the unification of the eight former TLCs. This area comprises of 16 wards and 75 villages with one town and two R293 towns. Their major economic activities are: Agriculture, mining, construction, trade, transport and finance.

\subsection{Data Collection}

A total of 200 questionnaires were administered in the two municipal areas. Greater Tubatse municipality consist of a population density of 335,676 (72.94 per $\left.\mathrm{km}^{2}\right)$ and 83,199 households while Ephraim Mogale comprises of a population density of 123,648 (61.48 per $\left.\mathrm{km}^{2}\right)$ and 32,284 households (Stats SA, 2011). Within each municipality several different villages were selected through the use of stratified random sampling technique; however, costs as well as the feasibility associated with the location of the selected village were taken into account when selecting villages. Sample survey on household level was obtained between the $10^{\text {th }}$ of July and $22^{\text {nd }}$ of September 2014.

The research was conducted within the following 20 villages: Phetoane, Tisimanyane, Letebejane, Masanteng, Mafisheng, Ditholong, Mohlalaotwane, Kolokotela, Dichoueng, Kromdraai, Ga-masha, GaMampuru, Ga-Phaspha, Ga-Mouru, Santeng, Mokotaseng, Mapodile, Ga-Manoke, Kgautswane and Puma.

\subsection{Statistical Analysis}

The Linear regression model was used to analyse the data and also to recognise the factors that determined the household food security in the study area. The model was used to generate regression factor score to determine the factor analysis as the dependent variable and also used the regression factor score on its independent variables. The Household Food Insecurity Access Scale (HFIAS) was used in the study as a survey 
instrument to find out whether households are having problems in accessing food for the past 30 days. The effectiveness of this tool has been discovered to check the severity level of household food insecurity. HFIAS was developed by the USAID which was funded by the Food and Nutrition Technical Assistance (FANTA). This was done in order to distinguish food secure and food insecure households.

The regression model specification is shown below:

$\hat{\boldsymbol{Y}}=\boldsymbol{\beta}_{\circ}+\boldsymbol{\beta}_{1} \mathbf{X}_{1}+\boldsymbol{\beta}_{2} \mathbf{X}_{2}+\boldsymbol{\beta}_{3} \mathbf{X}_{3} \ldots \ldots+\boldsymbol{\beta}_{\mathrm{k}} \mathbf{X}_{\mathrm{k}}+\boldsymbol{\varepsilon}$

Where $\hat{\boldsymbol{Y}}$ is the limited dependent variable Food security level of household head (1- SS/DD; $1=$ food secure, < $1=$ food insecure)

$\mathbf{X}_{\mathbf{1}}$ through $\mathbf{X}_{\mathbf{K}}$ are $\mathbf{k}$ distinct independent predictor variable

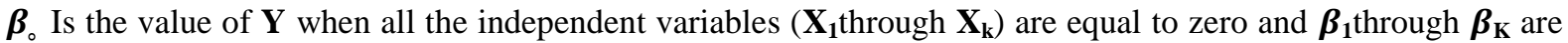
the estimated regression coefficients. The table 3.1 below explained and summarized the independent variables.

Table 1: Description of Variables used in the linear regression model

\begin{tabular}{|c|c|}
\hline Variable & Description \\
\hline Household size & Indicates number of people in the household \\
\hline Age & Indicate age of household head (years) \\
\hline Gender (Dummy) & $\begin{array}{l}\text { Indicate male/female headed of household } \\
1=\text { Male } 0=\text { Female }\end{array}$ \\
\hline Married (Dummy) & Indicates household head as married $(1=$ Married, $0=$ Not married \\
\hline Partner (Dummy) & Indicates household head as partner $(1=\mathrm{Yes}, 0=\mathrm{No})$ \\
\hline Divorced (Dummy) & Indicates household head as divorced $(1=\mathrm{Yes}, 0=\mathrm{No})$ \\
\hline Living apart not divorced (Dummy) & Indicates household head as living apart and not divorced $(1=\mathrm{Yes}, 0=\mathrm{No})$ \\
\hline Widow (Dummy) & Indicates household head as being a widow $(1=$ Yes, $0=\mathrm{No})$ \\
\hline Never married (Dummy) & Indicates household head as never married at all ( $1=$ Never married, $0=$ Married $)$ \\
\hline Employment status (Dummy) & Indicate employment status of household head $(1=$ Employed, $0=$ Otherwise $)$ \\
\hline Level of education (Dummy) & Indicate educational level of household head $(1=$ Educated, $0=$ Otherwise $)$ \\
\hline Household Sickness (Dummy) & Indicate household members with sickness $(1=$ Sick, $0=$ Otherwise $)$ \\
\hline Diabetes of diseased (Dummy) & Indicate household suffering from diabetes $(1=$ Have diabetes, $0=$ Otherwise $)$ \\
\hline $\begin{array}{l}\begin{array}{l}\text { Access to agricultural farmland } \\
\text { (Dummy) }\end{array} \\
\end{array}$ & Indicate the size of cropping land of households $(1=$ Access to farmland, $0=$ Otherwise $)$ \\
\hline Access to farm animals (Dummy) & Indicate household with access to farm animals ( $1=$ Access to animals, $0=$ Otherwise $)$ \\
\hline Household income (Rand) & Indicate household income per month \\
\hline Household food expenditure & Indicates household expenditure spent on food per month \\
\hline Household non-food expenditure & Indicates household expenditure on non - food activities per month \\
\hline Food crop production (Dummy) & Indicate households that produce food crops ( $1=$ Food crop production, $0=$ Otherwise $)$ \\
\hline Livestock production (Dummy) & Indicate household that rear livestock's $(1=$ Livestock production, $0=$ Otherwise $)$ \\
\hline Unskilled wage labour (Dummy) & $\begin{array}{l}\text { Indicate households with income from unskilled labour as their main source of income }(1= \\
\text { Yes, } 0=\text { Otherwise) }\end{array}$ \\
\hline Agricultural labour (Dummy) & $\begin{array}{l}\text { Indicates households with income from agricultural labour as their main income source }(1= \\
\text { Yes, } 0=\text { Otherwise) }\end{array}$ \\
\hline Salary/wages (Dummy) & $\begin{array}{l}\text { Indicate households with formal income as their main income source }(1=\text { formal income, } 0= \\
\text { Otherwise) }\end{array}$ \\
\hline $\begin{array}{l}\text { Pension, grants and disability funds } \\
\text { (Dummy) }\end{array}$ & $\begin{array}{l}\text { Indicates household with pension, grants and disability funds as their main income source }(1= \\
\text { Yes, } 0=\text { Otherwise) }\end{array}$ \\
\hline No shocks (Dummy) & Indicates household with no experience of shock in their household ( $1=$ Yes, $0=$ Otherwise $)$ \\
\hline Theft (Dummy) & $\begin{array}{l}\text { Indicates households that experience theft and robbery as shock experienced in their } \\
\text { household }(1=\text { Yes, } 0=\text { Otherwise) }\end{array}$ \\
\hline Death of household member (Dummy) & Indicate shock experienced through loss of household member $(1=$ Yes, $0=$ Otherwise $)$ \\
\hline Accident (Dummy) & $\begin{array}{l}\text { Shock experienced by household for reason of accident or chronic illness }(1=\text { Yes, } 0= \\
\text { Otherwise) }\end{array}$ \\
\hline $\begin{array}{l}\text { Loss or reduced unemployment } \\
\text { (Dummy) }\end{array}$ & $\begin{array}{l}\text { Indicates shock experienced through loss of employment of households }(1=\text { Yes, } 0= \\
\text { Otherwise) }\end{array}$ \\
\hline $\begin{array}{l}\text { Unusually high level of livestock } \\
\text { diseases (Dummy) }\end{array}$ & $\begin{array}{l}\text { Shock experienced by high level of livestock diseases }(1=\text { High livestock disease, } 0= \\
\text { Otherwise) }\end{array}$ \\
\hline $\begin{array}{l}\text { Unusually high level of crop pest } \\
\text { diseases (Dummy) }\end{array}$ & Indicates shock experienced by crop pest diseases $(1=$ Pest diseases, $0=$ Otherwise $)$ \\
\hline Drought (Dummy) & ck experienced through drought $(1=$ Yes, $0=$ Otherwise \\
\hline
\end{tabular}

\section{Results And Discussion}

3.1 Household's Demographic and socio-economic characteristics

The table 2 below shows the demographic characteristics of households. The samples consist of 200 households, of which $59 \%$ of households were headed by female and $41 \%$ were male headed. The average household size for the two municipalities was 4.4 while the majority of the households had 3 - 4 members. The average age of the household head is 52 years old which reflects an aging population of the household heads, which could in turn have crucial effect on household food security. About $20 \%$ of the household heads did not attend any form of schooling at all. This shows low level of education in the study area. The majority of the 
households, precisely $30 \%$ depend on government allowance such as grants, pension and disability benefits. Engagement in agricultural activities such as food crop production, livestock production and animal products contributes to the main income source for just about $21 \%$ household. Among the households, $21 \%$ engaged in unskilled wage labour, agricultural labour and skilled labour as main income source. About $40 \%$ of the households indicated that they had access to agricultural farm land and 55\% of the households indicated that they own farm animals. The most important livestock owned by households are cow, goat and chicken. Also, $26 \%$ of the households owned cows, whereas $21 \%$ owned goats, while $17 \%$ owned chicken.

Table 2: Demographic and socio-economic characteristics of respondents

\begin{tabular}{|c|c|c|c|}
\hline Household characteristics & Category & Frequency & Percentage $(\%)$ \\
\hline Gender & $\begin{array}{l}\text { Male } \\
\text { Female }\end{array}$ & $\begin{array}{l}82 \\
118\end{array}$ & $\begin{array}{l}41.0 \\
59.0\end{array}$ \\
\hline Age & $\begin{array}{l}20-30 \\
30-40 \\
40-50 \\
50-60 \\
60-70 \\
70-80\end{array}$ & $\begin{array}{l}6 \\
22 \\
30 \\
98 \\
38 \\
6\end{array}$ & $\begin{array}{l}3.0 \\
11.0 \\
15.0 \\
49.0 \\
19.0 \\
3.0\end{array}$ \\
\hline Average age & 52 & - & - \\
\hline Average Household size & 4.4 & - & - \\
\hline Marital status & $\begin{array}{l}\text { Married } \\
\text { Partner } \\
\text { Divorced } \\
\text { Living apart not divorced } \\
\text { Widow or Widower } \\
\text { Never married } \\
\end{array}$ & $\begin{array}{l}60 \\
17 \\
17 \\
12 \\
44 \\
50\end{array}$ & $\begin{array}{l}30 \\
8.5 \\
8.5 \\
6 \\
22 \\
25 \\
\end{array}$ \\
\hline Education level & $\begin{array}{l}\text { No schooling } \\
\text { Some primary } \\
\text { Completed primary } \\
\text { Some secondary } \\
\text { Completed secondary } \\
\text { Completed advance level } \\
\text { Completed tertiary } \\
\text { Completed university degree }\end{array}$ & $\begin{array}{l}40 \\
46 \\
36 \\
22 \\
32 \\
2 \\
16 \\
6 \\
\end{array}$ & $\begin{array}{l}20.0 \\
23.0 \\
18.0 \\
11.0 \\
16.0 \\
1.0 \\
8.0 \\
3.0\end{array}$ \\
\hline Employment status & $\begin{array}{l}\text { Full time employment } \\
\text { Par-time employment } \\
\text { Seasonal employment } \\
\text { Informal employment } \\
\text { Grant } \\
\text { Pension }\end{array}$ & $\begin{array}{l}80 \\
14 \\
14 \\
18 \\
40 \\
34\end{array}$ & $\begin{array}{l}40.0 \\
7.0 \\
7.0 \\
9.0 \\
20.0 \\
17.0\end{array}$ \\
\hline
\end{tabular}

\subsection{Household food production}

The average farm size under cultivation is 2.6 ha with standard deviation of (1.2ha). Farm holding ranges from 0.8 ha to 5.0 ha. This shows a low variation in farm holdings by households. In this study, $40 \%$ of the households indicated that they had access to agricultural farm land, while $60 \%$ did not practice agricultural farming system. The most widely cultivated crops are cereals. Maize appears to be the most widely grown cereal crop in the two municipal areas. Starchy vegetables /tuber only constitute $4 \%$ of the crops grown in the area while vegetables made up to $5 \%$ of the cultivated crops in the area. Majority of the households $55 \%$ indicated that they own farm animals. The most important livestock owned by households are cow, goat and chicken. Also, $26 \%$ of the households owned cows and $21 \%$ owned a goat, while $17 \%$ owned chicken.

\subsection{Household food consumption and food source}

In order to know how household meet their food needs, a food consumption assessment was carried out. This was centred on the number of frequencies a food type was eaten in the last seven days. The Figure below shows that maize product is the most consumed food in the past seven days before survey. 


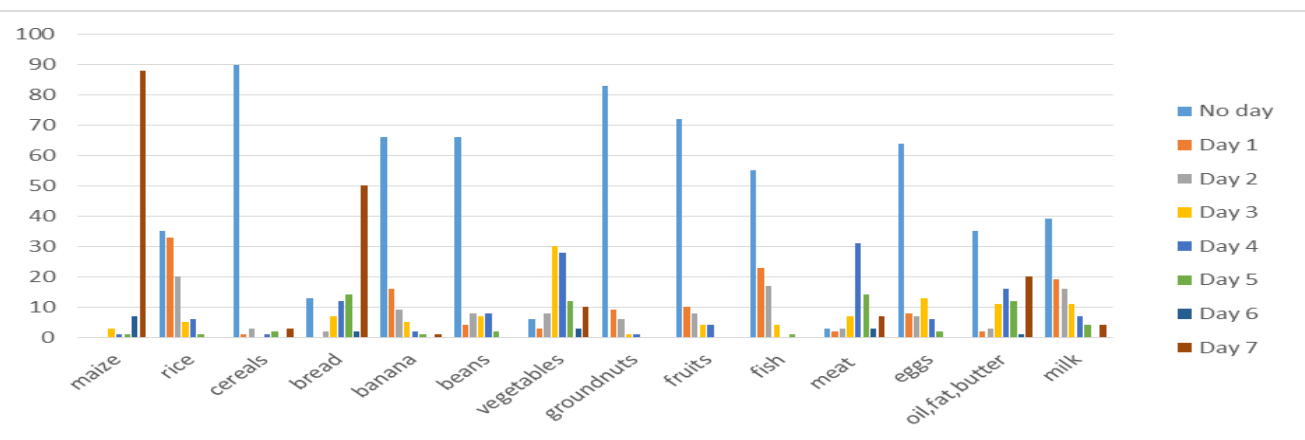

Fig 1. Household food consumption type over the last seven days

Also, information regarding the number of times both adults and children eat in a day was also captured. The result shows that $63 \%$ of adults eat twice in a day while $36 \%$ eats thrice daily. The children's daily eating pattern also shows that $53 \%$ ate two times in a day while $43 \%$ ate three times and $2 \%$ ate four times daily.

The majority of households in the study indicated that their main source of food consumption are from purchases. Others are owned production, gift from family members. $84 \%$ of households indicated that they purchase maize, $85 \%$ purchase bread, $35 \%$ purchase banana, $58 \%$ purchase vegetables, $87 \%$ purchase meat, $45 \%$ purchase milk, $62 \%$ purchase oil and butter, $29 \%$ purchase eggs, $43 \%$ purchase fish.

Source of food from owned production includes maize as $14 \%$ of households indicated they obtain them from their own production. Also, $16 \%$ of households produce their own vegetables, $7 \%$ produce meat $5 \%$ for eggs, $15 \%$ produces their own milk, $2 \%$ indicated production of fruits, $4 \%$ from groundnuts, $5 \%$ from beans.

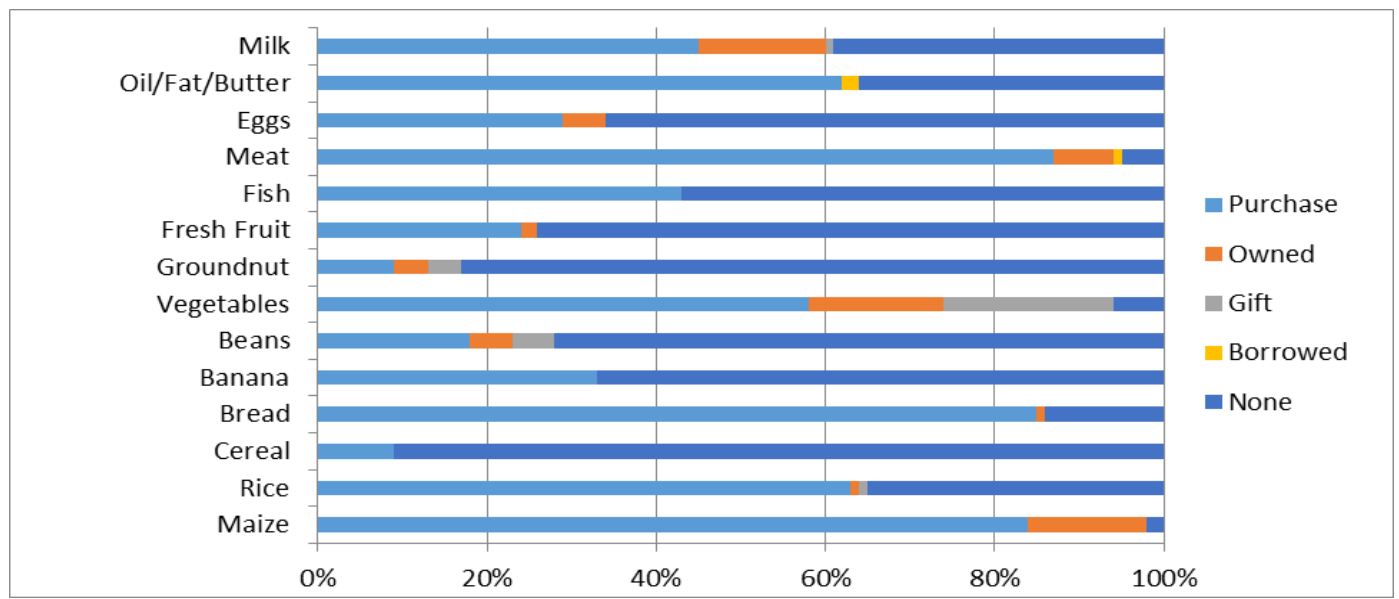

Fig 2. Percentage distribution of household food sources

\subsection{Common shocks and coping strategies}

The majority of the households indicated that they experience a form of shock in their households while only $13 \%$ never experience any form. About 37\% of households indicated that high prices of food is the most common shock experienced, $16 \%$ indicated that high levels of livestock diseases affects their farm animal which leads to a form of stress in their household. 9\% household experienced the death of a household member, $8 \%$ of households responded to high level of crop pests and diseases of crop grown. $7 \%$ household said they experienced drought/irregular rains. Other forms of stress experienced by household include loss of employment of a household member, severe illness or accident of a household member and death of a household working member. Majority of household suffered different type of diseases, about $28 \%$ have diabetes, $10 \%$ are physically disabled, 7\% have Tuberculosis, 3\% have HIV/AIDs and 3\% are mentally disabled. Diabetes seems to be the major chronic sickness suffered by household in the study. This is supported by Zanner et al. (2004) who indicated that severe health problems faced in Sekhukhune district are hypertension, diabetes, asthma and tuberculosis. 


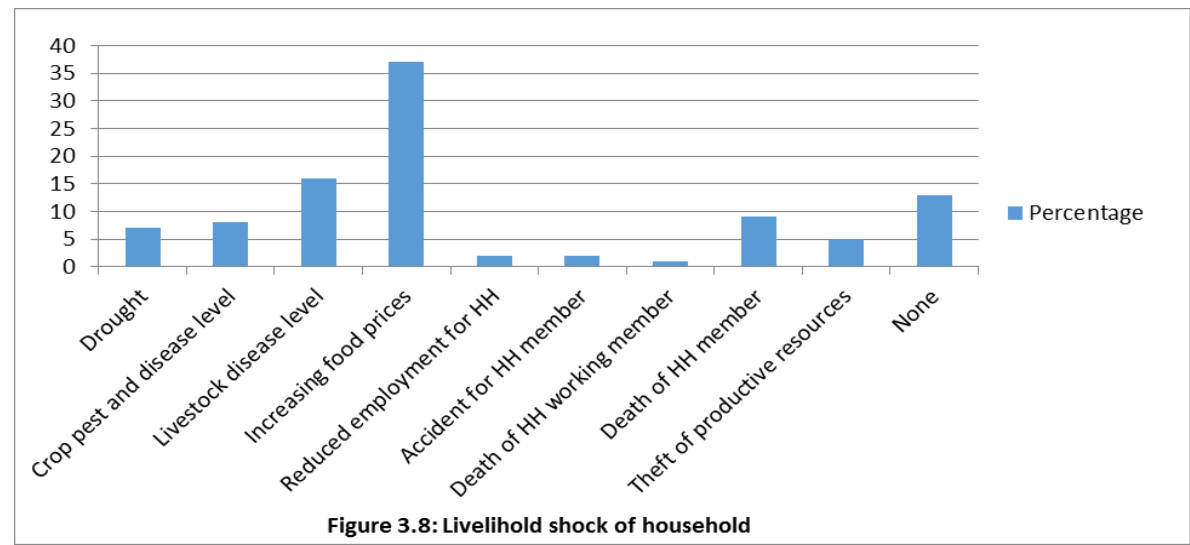

Fig 3. Household common shocks and stress experienced

\subsection{Impact of shocks on household}

Majority of households indicated that the shock has affected them negatively about $50 \%$ of households responded that shocks experienced had created a decrease or loss in their household income and in kind receipts. $14 \%$ claimed that shocks affected both their income and assets, eighteen percent experienced change in their assets (e.g. livestock, cash savings) while four percent mentioned that they didn't experience any change at all in their household.

Also sixty percent of respondents indicated that they experience a decrease in food availability due to shocks experienced in their households and twenty percent of the households never experienced any decrease in food availability. Five percent responded that they do not know if they have experienced any.

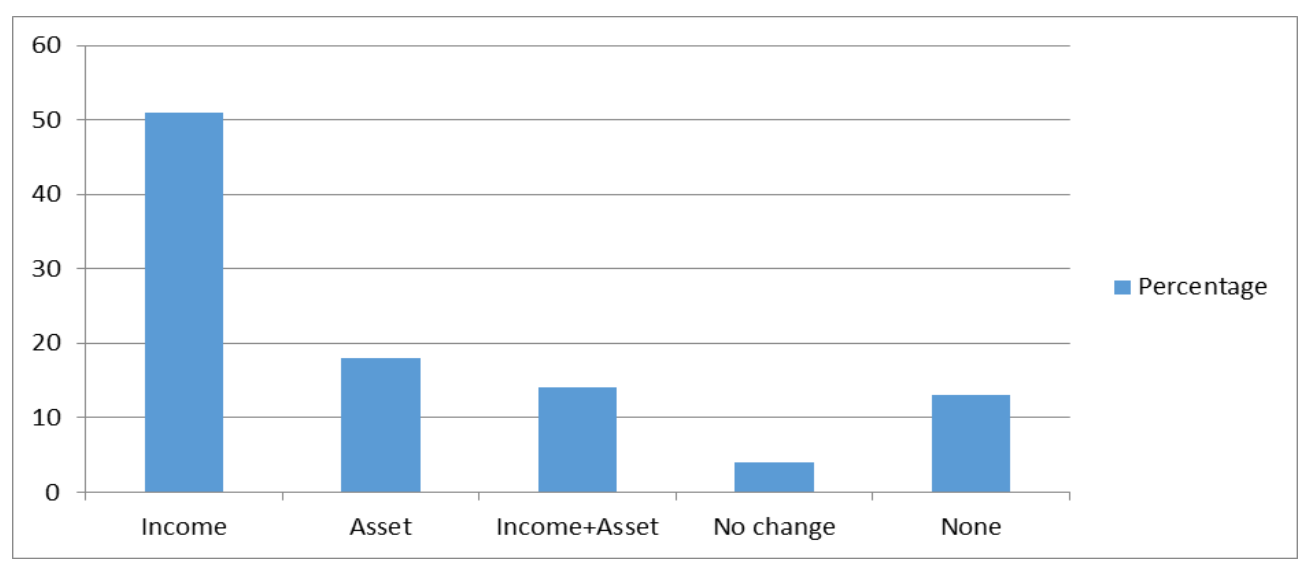

Fig 4. Impact of shock on household

\subsection{Coping strategies for food availability and shortage}

Majority of households rely on less preferred or less expensive food, $17 \%$ reduced the proportions of meals, $13 \%$ preferred to borrow money, $9 \%$ sold small animals like goats, sheep and pigs. Only few proportions of the respondents used other alternative methods such as purchasing food on credit, sold agricultural asset, borrowed food

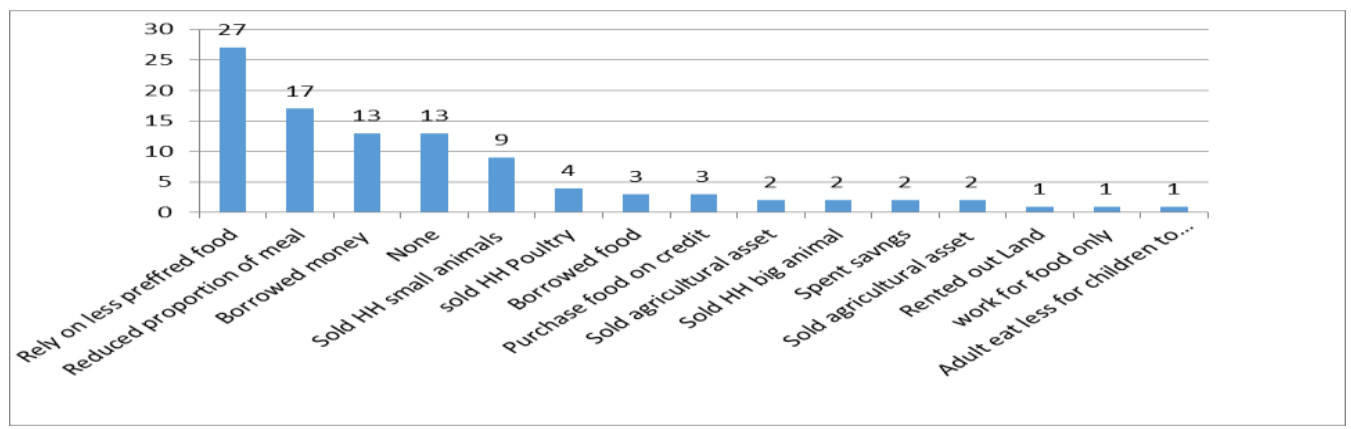

Fig 5. Household coping strategies for food shortage

\subsection{Food security status of Household}


The categorical designations of household food security status were based on the household food insecurity access scale (HFIAS), this scale was developed by the Food and Nutrition Technical Assistance (FANTA). The scale helps in categorizing households into four different levels of food insecurity. About $22.2 \%$ of inhabitants are food secure, $32.2 \%$ are mildly food insecure while $34.2 \%$ of the population are moderately food insecure and $11.4 \%$ of the people are severely food insecure. About $16 \%$ of the respondents are often worried about not having enough food for themselves and their families; $46 \%$ sometimes get worried while $20 \%$ rarely get worried and only $18 \%$ never get worried. $9 \%$ of the respondents often get worried about not being able to eat their preferred meal due to lack of resources; and quite differently, 50\% sometimes get worried and a proportion of $26 \%$ rarely eat their preferred meal. Only $15 \%$ of household members have enough resources to provide for themselves and eats whatever they like and only $12 \%$ of the respondents had access to different kinds of food while $13 \%$ often eat few kinds of food. About $29 \%$ rarely had access to different kinds of food, while in contrast, $46 \%$ sometimes experience difficulties in accessing food varieties in a month due to lack of resources. A ratio of $22 \%$ of the repondents agreed that they often eat food that are not preferabble because they could not afford to purchase the food they preferred. Meanwhile, 35\% indicated they sometimes eat unprefarrable meal due to lack of food accessibility, while $13 \%$ professed that they never experience any form of diffculty in eating their preferred meal. An aggregate of $36 \%$ of the household members indicated they sometimes ate fewer meals in a day while $14 \%$ indicated that such an experience often occurred consistently for 30 days. When asked how often household members went to sleep without eating, $18 \%$ of the respondents indicated they sometime went to bed hungry, $22 \%$ indicated they rarely went to bed without eating and only few respondents $3 \%$ indicated they often went to beg hungry. The results show that $43 \%$ of households live below the poverty line. When asked how often members spend a whole day without eating, only $1 \%$ of the respondents indicated that they often pass through such experience due to lack of food access. Contrariwise, $76 \%$ of household members said that they had never passed through such occurrence. On the other hand, $13 \%$ of respondents indicated that such cases rarely happen to them; while $10 \%$ of households said they sometimes went a whole day and night without eating any food.

\subsection{Percentage distribution of household food security level}

The Household Food Insecurity Access Prevalence was used to determine the percentage of household food security status. This is used to classify households into four dimensions of food insecurity categories such as, food secure, mildly food insecure, moderately food insecure and severely food insecure. The below shows that $22.2 \%$ of inhabitants are food secure, $32.2 \%$ are mildly food insecure while $34.2 \%$ of the population are moderately food insecure and $11.4 \%$ of the people are severely food insecure.

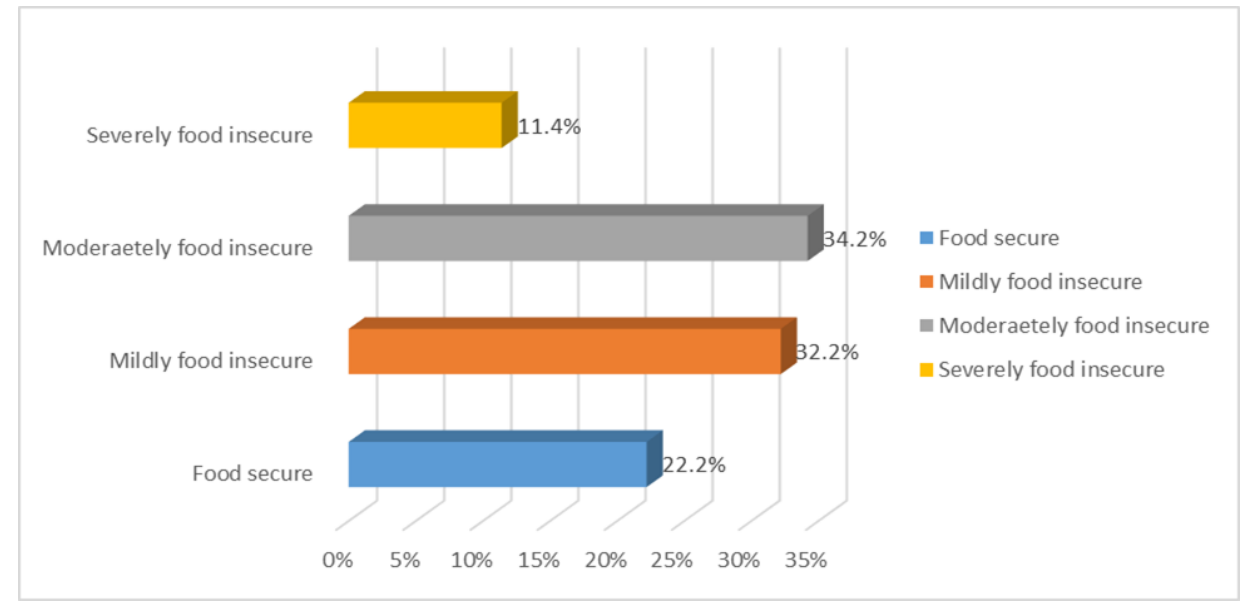

Figure 6. Percentage distribution of household food security level

\subsection{Determinants of Food Security}

According to the results shown in Table 3 majority of the variables had both positive and negative significant impact on household food security. From the analysis; household size, education, household chronic illness, diabetes, unskilled wage labour, pension, disability funds and grants, no shocks were found to have positive relationship to the probability of household being food secure while Gender, theft, death of an household member, illness or accidental loss or reduced employment, unusually high level of livestock diseases had a negative and significant impact on household food security.

Household size has a positive and significant effect on household food security at $5 \%$ level of significance. A unit increase in household size of the respondents will result in an increase of $6.1 \%$ of the food security of the household, with other factors held constant. The reason may be due to the fact that in South

DOI: $10.9790 / 2380-1004022332 \quad$ www.iosrjournals.org $\quad 29 \mid$ Page


Africa, government pays child grant to low income households, which implies that the more children a low income households have, the more children grants received which may result in better security of the household. This result is contrary to several findings from other researchers. Bashir et al, (2012) finds that in rural Pakistan, an additional increase of a household member reduces the opportunity of food security in households. Similar results was found in India by Sindhu et al., (2008) that an increase in family member increases the chances of a household becoming food insecure.

Education of household head had a positive and significant relationship with food security at $1 \%$ significant level. A strong correlation exists between education empowerment and food security (FAO, 2009). It further explained that formal or informal education as well as training skills are very useful and tends to improve the capacity of people to enhance food security. Food security can be effective and positive if household heads are literate and are willing to acquire new skills and ideals (Amaze, et al., 2006). Food insecurity in households will be absolutely reduced if household heads increase their level of education. Bashir et al, (2012) also specified that in rural Pakistan, household heads with middle class educational level such as grade $8-12$ significantly have positive impacts on household food security.

Livelihood activities such as unskilled wage labour have been found to have significant (1\%) and positive relationship with household food security. This implies that unskilled wage labour contributes effectively for a household to be food secure. Statistic SA (2013) indicated that commercial agriculture employs $5.2 \%$ of the South African labour forces, totalling over 600,000 people, most of which are unskilled or semiskilled workers with little formal education, such as mining, commercial agricultural labour forces etc. This shows that there is an oversupply of unskilled labour in the country.

The absolute dependency on social grants as a major source of income was significant and serves as one of the major determinant factors to measure household food security. Grants such as, old age pension, disability funds and child support were mostly given to rural household by the South African government. Many rural households in South Africa depend on various social grants to sustain livelihood. General household survey (2013) reported that more than $33.1 \%$ of households in Limpopo province depend mostly on grants and pension as their major source of income. The impact of social grants on food security has been discovered to improve the standard of living in rural households in South Africa. Old age pension played a significant role in reducing the rate of poverty in households with most of this money primarily used in acquiring food. Studies found that more than $90 \%$ of black South African old age adults have access to pension (Burns et al., 2005 and Ferreira, 2006).

Household chronic illness was found to have a positive impact on household food security at $10 \%$ significance level. This implies that households suffering from chronic illness or disability are food secured. This may be due to free medical health care services offered at public primary health care clinics and community health care centres in South Africa. This in turn enables the sick to have more money to spend on feeding themselves correctly in order to live a healthy life. This result is contrary to findings from various researchers. Masuku et al, (2009) explains that household member suffering from chronic illness may lead to income loss and poor outputs of agricultural activities. This may lead to household food insecurity due to extra spending on health care and also reduction of extra food expenditure or selling household properties for cash.

The effect of Diabetes on household food security was found to be significant at $10 \%$, meaning that diabetes has a positive impact on household food security. This result is also contrary to findings from other researchers. Diabetes is a chronic disease which has adverse effect on household through the high cost of treatment and high cost of nutritious food, including loss of income at work. According to Dyson (2009) diabetic individuals suffering from food insecurity is initiated by inappropriate meal intake and high consumption of sugary foods. She further explains that access to good health care and medication is disrupted because of poverty, which inturns leads to difficulties in acquiring proper meal due to high cost of getting medications.

Table 3. Parameter estimates of determinant of household food security

\begin{tabular}{|l|l|l|l|l|}
\hline Variable & $\begin{array}{l}\text { Unstandardized } \\
\text { coefficient }\end{array}$ & $\begin{array}{l}\text { Standardized } \\
\text { coefficient }\end{array}$ & $\begin{array}{l}\text { Standard } \\
\text { error }\end{array}$ & Significance level \\
\hline Constant & .695 & & .799 & .386 \\
\hline Household size & .061 & .144 & .028 & $.033^{* *}$ \\
\hline Age & -.007 & -.069 & .008 & .364 \\
\hline Gender & -.429 & -.211 & .145 & $.004^{* * *}$ \\
\hline Married & -.760 & -.350 & .629 & .229 \\
\hline Partner & -.553 & -.165 & .579 & .341 \\
\hline Divorced & -.700 & -.201 & .618 & .259 \\
\hline Living apart not divorced & -.546 & -.130 & .616 & .379 \\
\hline Widow or widower & -.679 & -.283 & .632 & .284 \\
\hline Never married & -.674 & -.293 & .620 & .279 \\
\hline Employment & -.122 & -.060 & .159 & .442 \\
\hline Education & .443 & .178 & .167 & $.009 * * *$ \\
\hline Household sickness & .255 & .123 & .136 \\
\hline
\end{tabular}


Assessment of Welfare Shocks and Food Insecurity in Ephraim Mogale and Greater ...

\begin{tabular}{|c|c|c|c|c|}
\hline Diabetes of diseases & .253 & .114 & .135 & $.063^{*}$ \\
\hline Access to farmland & .223 & .110 & .146 & .127 \\
\hline Access to farm animal & -.076 & -.038 & .144 & .597 \\
\hline Household income & .000 & -.268 & .000 & .815 \\
\hline Household food expenditure & .000 & .161 & .000 & .647 \\
\hline $\begin{array}{ll}\begin{array}{l}\text { Household } \\
\text { expenditure }\end{array} & \text { non-food } \\
\end{array}$ & -.005 & .000 & .115 & .130 \\
\hline Food Crop production & -.283 & -.077 & .331 & .394 \\
\hline Livestock Production & .271 & .090 & .252 & .285 \\
\hline Unskilled wage labour & 1.032 & .311 & .275 & $.000 * * *$ \\
\hline Agricultural labour & .105 & .027 & .312 & .736 \\
\hline Salary wages & .248 & .104 & .237 & .298 \\
\hline $\begin{array}{l}\text { Pension/disability funds and } \\
\text { grants }\end{array}$ & .551 & .254 & .236 & $.021 * *$ \\
\hline No Shocks & -1.200 & -.405 & .196 & $.000 * * *$ \\
\hline Theft & -.877 & -.192 & .301 & $.004 * * *$ \\
\hline Death of Household member & -.617 & -.186 & .208 & $.003 * * *$ \\
\hline Illness or accident & -.768 & -.108 & .455 & $.093 *$ \\
\hline Loss or reduced employment & -1.156 & -.163 & .440 & $.009 * * *$ \\
\hline $\begin{array}{l}\text { Unusually high level of } \\
\text { livestock stock diseases }\end{array}$ & -.547 & -.199 & .192 & $.005 * * *$ \\
\hline $\begin{array}{l}\text { Unusually high level of crop } \\
\text { pest diseases }\end{array}$ & .445 & .121. & .285 & .121 \\
\hline Drought & -.530 & -.136 & .291 & $.071 *$ \\
\hline \multicolumn{5}{|c|}{$.726^{\mathrm{a}}$} \\
\hline $\mathrm{R}^{2}$ & \multirow{2}{*}{\multicolumn{4}{|c|}{$\begin{array}{l}.433 \\
5.597\end{array}$}} \\
\hline alue & & & & \\
\hline bin-Watson & \multicolumn{4}{|l|}{2.022} \\
\hline
\end{tabular}

\section{Conclusion}

The study also found that the majority of households experience a form of shock. The most common shocks are high food prices, chronic illness and high level of livestock diseases. This makes a tremendous impact on households, thereby causing a decrease in food availability and on household income and assets. The majority of households relies on less preferred and less expensive food as their coping strategies for food shortage and availability.

In order to achieve this aim and address the problem of food insecurity in the study area, the study suggests further improvement in these four key areas.

Education. Education should be promoted in the study area. The majority of household head experienced no schooling at all. In this case, policy priorities should emphasize on rural education since the education of households tends to be a significant determinant of household food security.

Dependency on Social grants. The majority of households depends on social grants for their source of living. It is evident that social grants cannot solve the problem of food insecurity. Employment opportunities should be created and people should be encourage to work.

Employment. Informal income, such as unskilled wage labour has been discovered to be one of the most important sources of employment in the study area. Policy priorities should be given to high labour intensive growth. Government should create more jobs that are suitable for job seekers in this category.

Health. Government needs to intervene in order to promote health and nutrition education of dietary intake. Policies for caring for non-communicable disease in the country should be set and implemented.

\section{References}

[1]. Altman, M., T. Hart, and P. Jacobs, 2009. Food insecurity in South Africa, unpublished report, center for poverty employment and growth, Pretoria, Human Science Research Council.

[2]. Department of Agriculture Forestry and Fisheries. The integrated Food Security Strategy for South Africa 2002, [online] Accessed from www.daff.gov.za [Accessed: 2010-09-05]

[3]. Labadarios, D., Y.D. Davids, Z. Mchiza, and Weir-smith. 2009. The Assessment of food insecurity in South Africa, unpublished paper, center for poverty, employment and growth, HumanScience Research Council.

[4]. Jacobs, F.T., 2009. The status of household food security targets in South Africa. Agrekon, 48(4), 410-433.

[5]. Human Science Research Council (HSRC), 2007. Achieving food security in South Africa: characteristics, stressors and recommendations to 2019. Report to the office of the presidency (June 2007). Pretoria: human Science Research Council.

[6]. Shisana, O., D. Labadarios, T. Rehle, L. Simbayi and K. Zuma, 2014. South African National Health and Nutrition Examination Survey (SANHANES- 1): 2014 Edition. Cape Town: HSRC Press.

[7]. Agri SA 2015. Drought poses threat on food security. Source. http://www.agrisa.co.za/droughtposes-threat-to-food-security/. Accessed on $30^{\text {th }}$ November 2015. 02:03:11 GMT

[8]. IFAD. 2007. IFAD strategy paper on HIV/AIDS for East and Southern Africa. 19 January [Online] Available: http://www.ifad.org/operations/regional/pf/aids_2.htm: Accessed: 10 August 2009. 
[9]. Haldewang, B. 2009. AIDS Watch. Issue 33 August 2008. Cape Town: Institute for futures research, University of Stellenbosch

[10]. UNAIDS, WHO, 2007 December. 2007 AIDS epidemic update http://data.unaids.org/pub/EPIslides/2007/2007-epiupdate-cn.pdf

[11]. Statistics South Africa, 2011. General Household Survey, 2009. Pretoria: Statistics South Africa. Pp6-10.

[12]. Zanner, R.A., 2004. The role of information in rural livelihoods. BSc honours Thesis, University of Cape Town, Department of Environmental and Geographical Science, disaster mitigation program me for sustainable livelihoods, pp111.

[13]. Bashir, M.K., S. Schilizzi, and R. Pandit, 2012. The determinants of rural household food security in the Punjab, Pakistan: an econometric analysis, Working Paper 1203, School of Agricultural and Resource Economics, University of Western Australia,Crawley, Australia. Pp 18.

[14]. Sindhu, R.S., I. Kaur and K. Vatta, 2008. Food and nutritional insecurity and its determinants in food surplus areas: the case study of Punjab state. Agricultural Economics Research Review, 21: 91-98.

[15]. FAO. 2009. The state of agricultural commodity markets. Rome, Italy: Food and Agricultural Organization of the United States

[16]. Amaza, P.S., J.C. Umeh, J. Helsen and A.O. Adejobi, 2006. Determinants and measurement of food insecurity in Nigeria: some empirical policy guide". Presented at international association of agricultural economists' annual meeting, August 12-18, Queensland Australia. http://ageconsearch.umn.edu/bitstream/25357/1/pp060591.pdf

[17]. Statistics South Africa, 2013. State of agriculture in South Africa. Source. https://www.sablog.kpmg.co.za/2013/12/stateagriculture-south-africal. Accessed on 14 Dec 2016 23:41:48 GMT.

[18]. Burns, J., M. Keswell and M. Leibbrandt, 2005. Social assistance, gender, and the aged in South Africa. Feminist Economics, 11(2), $103---115$

[19]. Ferreira, M. (2006). The differential impact of social-pension income on household poverty alleviation in three South African ethnic groups. Ageing \& Society, 26(3), 337-354.

[20]. Masuku, M.B. and M.M. Sithole, 2009. The impact of HIV/AIDS on food security and household vulnerability in Swaziland

[21]. Dyson, Pamela. Food insecurity: what does it mean to people with diabetes? "PracticalDiabetes 29.3 (2012): 89-90a. 